\title{
Cutaneous squamous cell carcinoma
}

\section{Risk factors and new systemic treatment options in advanced disease}

\author{
Magdalena Seidl-Philipp (ID · Van Anh Nguyen
}

Received: 12 October 2019 / Accepted: 26 November 2019 / Published online: 8 January 2020

(C) The Author(s) 2020

\begin{abstract}
Summary Cutaneous squamous cell carcinoma (cSCC) accounts for approximately $20 \%$ of all skin cancers. Its rising incidence represents a major public health concern. The majority of cSCC are curable by surgical resection. Although less than $5 \%$ of cSCC patients develop metastases or local recurrence after complete excision, advanced cSCC is difficult to treat. Until recently, no standard therapeutic regimen for advanced cSCC exists. Traditional therapies include chemotherapy and EGFR-targeted therapy, but their clinical benefit remains modest and has been demonstrated mostly in retrospective studies. On the contrary, PD-1 inhibitors dramatically improve outcomes in many immunocompetent cSCC patients, resulting in the approval of cemiplimab as the first FDA-approved systemic drug for patients with locally advanced or metastatic cSCC who are not candidates for curative surgery or radiation. In the coming years combination therapies are an emerging treatment strategy that could improve efficacy of PD-1 inhibitors in advanced cSCC. Moreover, several prospective controlled trials have been designed to explore the potential role of PD-1 inhibitors in the adjuvant and neodjuvant setting. Given the paucity of data, the management of immunocompromised cSCC patients requires a heightened awareness in this new era of cancer therapeutics.
\end{abstract}

\footnotetext{
M. Seidl-Philipp $(\bowtie) \cdot$ V. A. Nguyen

Department of Dermatology, Venereology and

Allergology, Medical University of Innsbruck,

Anichstr. 35, 6020 Innsbruck, Austria

magdalena.philipp@i-med.ac.at

V. A. Nguyen

Van.Nguyen@i-med.ac.at
}

Keywords Non melanoma skin cancer . Immunotherapy · Checkpoint inhibitors · PD-1inhibitors · Organ transplant recipients

\section{Introduction}

Cutaneous squamous cell carcinoma (cSCC) accounts for approximately $20 \%$ of all skin cancers and is after basal cell carcinoma (BCC) the second most frequent form of nonmelanoma skin cancer (NMSC) [1]. The incidence of NMSC continues to rise since 1960 [2] and represents a major challenge for healthcare systems [3].

CSCC occurs predominantly on sun-exposed skin sites and is associated with high cumulative UV doses [4]. Phenotypic traits to develop cSCC are light hair, skin and eye colour [4]. Further major risk factors include older age [4] and immunosuppression [5]. It has been shown that white transplant recipients have a 65fold higher risk of cSCC compared with the nontransplanted population [5]. The risk of developing cSCC is also increased in patients suffering from human immunodeficiency virus infection (HIV) and haematological diseases like non-Hodgkin lymphoma and chronic lymphatic leukaemia [4].

In most cases cSCC has a good prognosis and is curable by surgical resection. Nevertheless, a small percentage of patients progress to locally advanced or to metastasizing carcinoma [6]. A metastatic rate of $1.9-2.6 \%$ has been reported [7]. Regional lymph nodes are affected in approximately $85 \%$ of all cases, whereas the lungs, liver, brain and bones are less common sites of metastasis. The 10-year survival rates fall to less than $20 \%$ in case of locoregional lymph node metastases and less than $10 \%$ in the presence of distant metastases [6].

Risk factors for developing advanced cSCC are summarized in Table 1. Especially long-lasting and intense 
Table 1 Risk factors for developing advanced cSCC

High-risk factors in cSCC
Tumour size (diameter) $>2 \mathrm{~cm}$
Depth of invasion $\geq 6 \mathrm{~mm}$
Tumour site on ear, lip or areas of long-lasting chronic ulcers or inflamma-
tion
Acantholytic, spindle cell or desmoplastic histological subtype
Perineural involvement
Host immunosuppression
Recurrent lesions
Adapted from [4] and [10]

immunosuppression can induce rapid tumour growth and increase the probability for local recurrence and metastatic spread $[8,9]$. Other risk factors associated with poor outcome have been identified, including large tumour diameter, lesion thickness, poor histological differentiation, location on the ear or lip and perineural involvement $[4,10]$.

There is no recommended standard therapeutic regimen for advanced cSCC and the number of randomized controlled trials are limited [10]. Radiotherapy \pm chemotherapy is considered as a conventional option for locally or regionally advanced disease [10-12]. Systemic chemotherapy and EGFRtargeted therapy are traditionally applied in patients with distant metastasis [10]. The use of chemotherapy has been explored mainly through retrospective studies and case series [10]. Reported overall response rates (ORR) with platinum monotherapy ranged from $17 \%$ to $78 \%$, albeit these responses were typically short-lived and overall survival was not substantially extended [13]. ORR higher than $80 \%$ have been reported to polychemotherapy with cisplatin in combination with 5-fluourouracil and/or bleomycin [13, 14], but these results were only transient and not confirmed by subsequent studies [10]. Moreover, the toxicity profile of polychemotherapy precludes its use in a largely geriatric patient population with pre-existing comorbidities [10]. The EGFR-inhibitor cetuximab is preferentially used as subsequent line treatment when chemotherapy is unfeasible or there is a progressive disease [10]. In a phase II clinical trial cetuximab showed an ORR of $28 \%$ and a median progression-free survival (PFS) of 4.1 months with less toxicity in patients with locally advanced and metastatic cSCC [15]. In smaller studies higher ORR could be achieved when combined with chemotherapy and/or radiotherapy. Yet, median PFS remained still short in most cases [16].

Recently, data of 190 unselected patients with advanced cSCC who were diagnosed between 2010 and 2011 in Germany and Austria were analysed retrospectively with regard to patient profiles and treatment patterns, thus reflecting real-life conditions. In all, $40 \%$ of the patients suffered from locally advanced and $60 \%$ from metastatic cSCC. Only 32 patients, 3 with locally advanced and 29 with metastatic cSCC, were treated with systemic antitumour regimens, in most cases with EGFR-inhibitor based therapies. ORR was $26 \%$ and median duration of response was 5 months [17]. These data confirm that chemotherapy and EGFR-targeted therapy offer only modest clinical benefit. Hence, there is a critical unmet need for improved advanced cSSC treatment. Checkpoint immunotherapy represents a promising new treatment option for inoperable cSCC.

\section{PD1-based immunotherapy-a new systemic treatment option in advanced cSCC}

The blocking of the PD1/PD-L1 pathway can enhance T-cell-activity and consequently promote tumour immunosurveillance [18]. In the last few years, the checkpoint inhibitors have been highly discussed as a promising treatment option for patients with advanced cSCC. The critical role of the immune system in controlling the development and growth of cSCC is well-known as cSSC diagnosed in immunosuppressed organ transplant recipients is more likely to show unfavourable prognostic features and to metastasize [5, 8]. Furthermore, findings such as high UV-mutation burden, infiltration with lymphocytes and PD-L1 expression in high-risk disease strongly indicate that targeting the immune system with PD-1 inhibitors could be effective in advanced cSSC [19-21].

The first case reports documenting the efficacy of the PD-1 inhibitors pembrolizumab and cemiplimab in advanced cSCC were published in 2016 [22, 23]. In September 2018, the PD-1 inhibitor cemiplimab became the first FDA-approved systemic drug for patients with locally advanced or metastatic cSCC who are not candidates for curative surgery or radiation [24]. Approval in Europe followed in July 2019. The approval was based on the results of a combined phase I/II clinical trial involving 85 patients, 75 with metastatic disease and 8 with locally advanced disease [25]. Most had undergone previous treatments, including prior radiation therapy and chemotherapy. $81 \%$ of pretreatment tumour samples were positive for PD-L1 expression. The results showed a quick onset of the clinical response after about 2 months with an ORR of $50 \%$ and a durable disease control rate (DCR) of $65.4 \%$. A partial response (PR) was observed in 24 patients and a complete response (CR) in 4 patients. Similar efficacy was observed in patients with regional metastatic disease and in those with distant metastatic disease. The ORR was clearly associated with the status of prior systemic treatments: patients without prior systemic treatment had an ORR close to $60 \%$ and those with prior systemic treatment had an ORR close to $40 \%$. The median duration of response (DOR) had not been reached and the estimated PFS probability at 1 year was $53 \%$, whereas the probability of survival at 1 year was more than $80 \%$. Most of the adverse events related to treatment were grade 1 or 2. Serious adverse effects accounted for less than 
Table 2 PD-1/PD-L1 based immunotherapy in advanced CSCC - ongoing clinical trials as listed on ClinicalTrials.gov [27]

\begin{tabular}{|c|c|c|c|c|c|}
\hline NCT identifier & Study title & Phase & Status & Cancer type & Drug \\
\hline NCT02760498 & $\begin{array}{l}\text { Study of REGN2810 in patients with advanced cutaneous } \\
\text { squamous cell carcinoma }\end{array}$ & Phase 2 & Recruiting & Advanced cSCC & Cemiplimab \\
\hline NCT02964559 & $\begin{array}{l}\text { Pembrolizumab in patients with locally advanced or } \\
\text { metastatic skin cancer }\end{array}$ & Phase 2 & Recruiting & Advanced cSCC & Pembrolizumab \\
\hline NCT03284424 & $\begin{array}{l}\text { Study of pembrolizumab (MK-3475) in adults with re- } \\
\text { current/metastatic cutaneous squamous cell carci- } \\
\text { noma (CSCC) or locally advanced unresectable cSCC } \\
\text { (MK-3475-629/KEYNOTE-629) }\end{array}$ & Phase 2 & $\begin{array}{l}\text { Active, not } \\
\text { recruiting }\end{array}$ & Advanced cSCC & Pembrolizumab \\
\hline NCT03834233 & $\begin{array}{l}\text { Nivolumab in patients with advanced cutaneous squa- } \\
\text { mous cell carcinoma (CA209-9JC) }\end{array}$ & Phase 2 & Recruiting & Advanced cSCC & Nivolumab \\
\hline NCT03737721 & $\begin{array}{l}\text { The UNSCARRed study: unresectable squamous cell } \\
\text { carcinoma treated with avelumab and radical radiotherapy } \\
\text { (UNSCARRed) }\end{array}$ & Phase 2 & Recruiting & Unresectable cSCC & $\begin{array}{l}\text { Avelumab with radical radio- } \\
\text { therapy }\end{array}$ \\
\hline NCT03944941 & $\begin{array}{l}\text { Avelumab with or without cetuximab in treating patients } \\
\text { with advanced skin squamous cell cancer }\end{array}$ & Phase 2 & Recruiting & Metastatic cSCC & Avelumab, Cetuximab \\
\hline NCT03082534 & $\begin{array}{l}\text { Pembrolizumab combined with cetuximab for treatment } \\
\text { of recurrent/metastatic head and neck squamous cell } \\
\text { carcinoma }\end{array}$ & Phase 2 & Recruiting & $\begin{array}{l}\text { Advanced HNSCC and } \\
\text { cSCC }\end{array}$ & Pembrolizumab, Cetuximab \\
\hline NCT03666325 & $\begin{array}{l}\text { Immunotherapy } \pm \text { EGFR inhibitor in advanced/metastatic } \\
\text { cSCC: tackling primary and secondary resistance (I- } \\
\text { Tackle) }\end{array}$ & Phase 2 & $\begin{array}{l}\text { Not yet } \\
\text { recruiting }\end{array}$ & Advanced cSCC & Pembrolizumab, Cetuximab \\
\hline NCT04050436 & $\begin{array}{l}\text { Study evaluating cemiplimab alone and combined with } \\
\text { RP1 in treating advanced squamous skin cancer (CER- } \\
\text { PASS) }\end{array}$ & Phase 2 & Recruiting & Advanced cSCC & $\begin{array}{l}\text { Cemiplimab, RP1 (geneti- } \\
\text { cally modified herpes sim- } \\
\text { plex type } 1 \text { virus) }\end{array}$ \\
\hline NCT03901573 & High-risk skin cancers with atezolizumab plus NT-I7 & Phase $1 / 2$ & $\begin{array}{l}\text { Not yet } \\
\text { recruiting }\end{array}$ & $\begin{array}{l}\text { Advanced CSCC and } \\
\text { others }\end{array}$ & $\begin{array}{l}\text { Atezolizumab + NT-17 } \\
\text { (recombinant human } \\
\text { IL-7-hybrid Fc) }\end{array}$ \\
\hline NCT03684785 & $\begin{array}{l}\text { Intratumoral AST-008 combined with pembrolizumab in } \\
\text { patients with advanced solid tumours }\end{array}$ & $\begin{array}{l}\text { Phase } \\
1 \mathrm{~b} / 2\end{array}$ & Recruiting & $\begin{array}{l}\text { Advanced CSCC and } \\
\text { others }\end{array}$ & $\begin{array}{l}\text { AST-008 (TLR9 agonist } \\
\text { SNA), Pembrolizumab }\end{array}$ \\
\hline NCT02955290 & $\begin{array}{l}\text { CIMAvax vaccine, nivolumab, and pembrolizumab in } \\
\text { treating patients with advanced non-small cell lung cancer } \\
\text { or squamous head and neck cancer }\end{array}$ & Phase $1 / 2$ & Recruiting & $\begin{array}{l}\text { Advanced CSCC of the } \\
\text { head and neck and } \\
\text { others }\end{array}$ & $\begin{array}{l}\text { Recombinant human } \\
\text { EGF-rP64K/montanide } \\
\text { ISA } 51 \text { vaccine (CIMAvax) } \\
\text { and Nivolumab or Pem- } \\
\text { brolizumab }\end{array}$ \\
\hline NCT03871348 & $\begin{array}{l}\text { A first-in-human dose escalation and expansion study } \\
\text { to evaluate intratumoural administration of SAR441000 } \\
\text { as monotherapy and in combination with cemiplimab in } \\
\text { patients with advanced solid tumours }\end{array}$ & Phase 1 & Recruiting & $\begin{array}{l}\text { Advanced cSCC and } \\
\text { others }\end{array}$ & SAR441000, Cemiplimab \\
\hline NCT03590054 & $\begin{array}{l}\text { A phase } 1 \mathrm{~b} \text { dose escalation/expansion study of abexino- } \\
\text { stat in combination with pembrolizumab in patients with } \\
\text { advanced solid tumour malignancies }\end{array}$ & $\begin{array}{l}\text { Phase } \\
1 \mathrm{~b} / 2\end{array}$ & Recruiting & $\begin{array}{l}\text { Advanced cSCC of the } \\
\text { head and neck and } \\
\text { others }\end{array}$ & Abexinostat, Pembrolizumab \\
\hline NCT03773744 & $\begin{array}{l}\text { MG1-MAGEA3 with Ad-MAGEA3 and pembrolizumab in } \\
\text { patients with previously treated metastatic melanoma or } \\
\text { cutaneous squamous cell carcinoma (Pelican) }\end{array}$ & Phase 1 & $\begin{array}{l}\text { Not yet } \\
\text { recruiting }\end{array}$ & $\begin{array}{l}\text { Metastatic cSCC and } \\
\text { others }\end{array}$ & $\begin{array}{l}\text { Ad-MAGEA3, MG-1MAGEA3, } \\
\text { Pembrolizumab, Cyclophos- } \\
\text { phamide }\end{array}$ \\
\hline NCT04007744 & $\begin{array}{l}\text { Sonidegib and pembrolizumab in treating patients with } \\
\text { advanced solid tumours }\end{array}$ & Phase 1 & $\begin{array}{l}\text { Not yet } \\
\text { recruiting }\end{array}$ & $\begin{array}{l}\text { Advanced cSCC of the } \\
\text { head and neck and } \\
\text { others }\end{array}$ & Sonidegib, Pembrolizumab \\
\hline NCT03108131 & $\begin{array}{l}\text { Cobimetinib and atezolizumab in treating participants with } \\
\text { advanced or refractory rare tumours }\end{array}$ & Phase 2 & Recruiting & $\begin{array}{l}\text { Advanced cSCC and } \\
\text { others }\end{array}$ & Cobimetinib, Atezolizumab \\
\hline NCT03565783 & $\begin{array}{l}\text { Cemiplimab in treating participants with recurrent stage } \\
\text { III-IV head and neck squamous cell cancer before surgery }\end{array}$ & Phase 2 & Recruiting & $\begin{array}{l}\text { Advanced CSCC of the } \\
\text { head and neck and } \\
\text { HNSCC (neoadjuvant) }\end{array}$ & Cemiplimab \\
\hline NCT03969004 & $\begin{array}{l}\text { Study of adjuvant cemiplimab versus placebo after } \\
\text { surgery and radiation therapy in patients with high-risk } \\
\text { cutaneous squamous cell carcinoma }\end{array}$ & Phase 3 & Recruiting & $\begin{array}{l}\text { High-risk cSCC (adju- } \\
\text { vant) }\end{array}$ & Cemiplimab, Placebo \\
\hline NCT03833167 & $\begin{array}{l}\text { Pembrolizumab versus placebo following surgery and } \\
\text { radiation in participants with locally advanced cutaneous } \\
\text { squamous cell carcinoma (MK-3475-630/KEYNOTE-630) }\end{array}$ & Phase 3 & Recruiting & $\begin{array}{l}\text { Locally advanced } \\
\text { cSSC (adjuvant) }\end{array}$ & Pembrolizumab \\
\hline NCT03057613 & $\begin{array}{l}\text { The addition of pembrolizumab to postoperative radiother- } \\
\text { apy in cutaneous squamous cell cancer of the head and } \\
\text { neck }\end{array}$ & Phase 2 & Recruiting & $\begin{array}{l}\text { High-risk cSCC of } \\
\text { the head and neck } \\
\text { (adjuvant) }\end{array}$ & Pembrolizumab \\
\hline NCT03816332 & $\begin{array}{l}\text { Tacrolimus, nivolumab, and ipilimumab in treating kid- } \\
\text { ney transplant recipients with selected unresectable or } \\
\text { metastatic cancers }\end{array}$ & Phase 1 & Recruiting & $\begin{array}{l}\text { Metastatic CSCC and } \\
\text { others }\end{array}$ & $\begin{array}{l}\text { Nivolumab, Ipilimumab, } \\
\text { Prednisolon, Tacrolimus }\end{array}$ \\
\hline
\end{tabular}


$10 \%$. The most common adverse events of any grade were diarrhoea $(27 \%)$, fatigue $(24 \%)$, nausea $(17 \%)$, constipation $(15 \%)$ and rash $(15 \%)$. There were 4 reported deaths due to adverse events. Of note, none were immune-related. Despite the advanced age of the patients (median age of patients over 70 years) no new safety signals were reported [25], suggesting that high age does not influence the efficacy and safety of the immunotherapy although patients enrolled in clinical trials have usually a better performance status compared with real-world patients.

The importance of PD-1 inhibitors has been further supported by preliminary data of a phase II trial with pembrolizumab on 39 patients, naive of chemotherapy and of EGFR inhibitors, with unresectable and/or metastatic cSCC and a median age of 80 showing an ORR of $42 \%$ and a median PFS of 7 months. Baseline PD-L1 expression was positive in 58\%. Reported adverse events were consistent with previous studies. There were no severe adverse events or immune-related deaths [26].

Great interest currently exists in ongoing clinical trials evaluating the efficacy of immune checkpoint inhibitors in unresectable cSCC, especially in combination with other treatment modalities [27], (Table 2). PD1 inhibitors are also tested in the adjuvant and neoadjuvant setting. Two phase III and one phase II clinical trial are evaluating adjuvant cemiplimab and pembrolizumab following surgery and radiation in patients with high-risk locally advanced cSCC (NCT03969004, NCT03833167, NCT03057613). The application of neoadjuvant cemiplimab is being investigated in a phase II clinical trial in patients with advanced resectable cSCC of the head and neck followed by definitive local surgery and radiation (NCT03565783) [27].

As mentioned, organ transplant recipients are much more likely to develop cSSC than the general population [5]. Unfortunately, data regarding safety and efficacy of immune checkpoint inhibitors in this population are lacking. Routinely, those patients are excluded from immunotherapy trials due to safety concerns. There is emerging evidence that these agents may lead to graft rejection although there are reports in which immune checkpoint inhibitors have been used without resulting in organ rejection $[28,29]$. A recent review, which included 57 organ transplant recipients receiving immune checkpoint inhibitors, reported graft rejection in $37 \%$ of patients and death due to graft rejection in $14 \%$ [30]. Most deaths $(51 \%)$ were related to progression of malignancy. The highest rejection rate was seen in patients with kidney transplants $(40.1 \%)$, followed by liver (35\%) and heart (20\%) transplants. Interestingly, 52\% of patients receiving nivolumab experienced graft rejection, in contrast with $25 \%$ receiving ipilimumab and $26.7 \%$ receiving pembrolizumab. Time from transplantation and choice of immunosuppression at the time of treatment with immunotherapy might be important factors for the outcome [30]. Another study, presenting the largest single-centre cohort of organ transplant recipients being treated with checkpoint inhibitor therapy, reported graft rejection in $41 \%$ and death primarily from allograft rejection or rejection complications in $46 \%$ of patients. The median time to rejection was 21 days and rejection rates were similar for anti-CTLA-4 and anti-PD- 1 therapy. Also, no association was observed between time since organ transplantation and frequency, timing or type of rejection [31]. These data indicate that further studies are clearly needed to delineate a subset of organ transplant recipients who might benefit from immunotherapy. In this respect, a phase I clinical trial is examining kidney transplant recipients with selected unresectable cancers including cSCC who are treated with tacrolimus, nivolumab and ipilimumab (NCT03816332) [27].

\section{Take home message}

A new era in the treatment of advanced cSCC has been paved by the approval of the PD-1 inhibitors cemiplimab and pembrolizumab. Clinical studies with PD-1 inhibitors led to dramatically improved outcomes in many immunocompetent cSCC patients. Questions to be answered in the coming years will be whether response rates can be further improved by combination therapies and whether PD1 inhibitors are also effective in the adjuvant and neoadjuvant setting. Additional critical questions include the usage of immune checkpoint inhibitors in immunocompromised cSCC patients who have the highest medical need for new therapeutic options.

Funding Open access funding provided by University of Innsbruck and Medical University of Innsbruck.

Conflict of interest M. Seidl-Philipp reports financial support from BMS outside the submitted work. V.A. Nguyen reports speaker's honoraria and consultancy fees from BristolMyers Squibb and Merck Sharp \& Dohme outside the submitted work.

Open Access This article is licensed under a Creative Commons Attribution 4.0 International License, which permits use, sharing, adaptation, distribution and reproduction in any medium or format, as long as you give appropriate credit to the original author(s) and the source, provide a link to the Creative Commons licence, and indicate if changes were made. The images or other third party material in this article are included in the article's Creative Commons licence, unless indicated otherwise in a credit line to the material. If material is not included in the article's Creative Commons licence and your intended use is not permitted by statutory regulation or exceeds the permitted use, you will need to obtain permission directly from the copyright holder. To view a copy of this licence, visit http://creativecommons. org/licenses/by/4.0/. 


\section{References}

1. Rogers HW, Weinstock MA, Harris AR, et al. Incidence estimate of nonmelanoma skin cancer in the United States, 2006. Arch Dermatol. 2010;146(3):283-7.

2. Green A. Changing patterns in incidence of non-melanoma skin cancer. Epithelial Cell Biol. 1992;1(1):47-51.

3. Stang A, Stausberg J, Boedeker W, et al. Nationwide hospitalization costs of skinmelanomaandnon-melanoma skin cancer in Germany. J Eur Acad Dermatol Venereol. 2008;22(1):65-72.

4. Madan V, Lear JT, Szeimies RM. Non-melanoma skin cancer. Lancet. 2010;375(9715):673-85.

5. O’Reilly Zwald F, Brown M. Skin cancer in solid organ transplant recipients: advances in therapy and management: part I.Epidemiology of skin cancer in solid organ transplant recipients. J Am Acad Dermatol. 2011;65(2):253-61.

6. Alam M, Ratner D. Cutaneous squamous-cell carcinoma. NEngl J Med. 2001;344(13):975-83.

7. Brougham ND, Dennett ER, Cameron R, Tan ST. The incidence of metastasis from cutaneous squamous cell carcinoma and the impact of its risk factors. J Surg Oncol. 2012;106(7):811-5.

8. Martinez JC, Otley CC, Stasko T, et al. Defining the clinical course of metastatic skin cancer in organ transplant recipients: a multicenter collaborative study. Arch Dermatol. 2003;139(3):301-6.

9. Dantal J, Hourmant M, Cantarovich D, et al. Effect of long-term immunosuppression in kidney-graft recipients on cancer incidence: randomised comparison of two cyclosporin regimens. Lancet. 1998;351(9103):623-8.

10. Stratigos A, GarbeC, LebbeC, et al. Diagnosis and treatment of invasive squamous cell carcinoma of the skin: European consensus-based interdisciplinary guideline. Eur J Cancer. 2015;51(14):1989-2007.

11. Nottage MK, Lin C, Hughes BG, et al. Prospective study of definitive chemoradiation in locally or regionally advanced squamous cell carcinoma of the skin. Head Neck. 2017;39(4):679-83. https://doi.org/10.1002/hed.24662.

12. S3 Leitlinie Aktinische Keratose und Plattenepithelkarzinom der Haut, Juni 2019

13. Sadek H, Azli N, Wendling JL, et al. Treatment of advanced squamous cell carcinoma of the skin with cisplatin, 5-fluorouracil, and bleomycin. Cancer. 1990;66:1692-6.

14. Khansur T, Kennedy A. Cisplatin and 5-fluorouracil for advanced locoregional and metastatic squamous cell carcinoma of the skin. Cancer. 1991;67(8):2030-2.

15. Maubec E, Petrow P, Scheer-Senyarich I, et al. Phase II study of cetuximab as first-line single-drug therapy in patients with unresectable squamous cell carcinoma of the skin. JClin Oncol. 2011;29(25):3419-26.

16. Dereure O, Missan H, Girard C, et al. Efficacy and tolerance of cetuximab alone or combined with chemotherapy in locally advanced or metastatic cutaneous squamous cell carcinoma: an open study of 14 patients. Dermatology. 2016;232(6):721-30.

17. Hillen U, Leiter U, Haase S, et al. Advanced cutaneous squamous cell carcinoma: A retrospective analysis of patient profiles and treatment patterns-Results of a non-interventional study of the DeCOG. EurJ Cancer. 2018;96:34-43.

18. Bottomley MJ, Thomson J, Harwood C, et al. The role of the immune system in cutaneous squamous cell carcinoma. Int J Mol Sci. 2019;20(8):E2009.
19. Goodman AM, Kato S, Bazhenova L, et al. Tumor mutational burden as an independent predictor of response to immunotherapy in diverse cancers. Mol Cancer Ther. 2017;16(11):2598-608.

20. Haeffner AC, Zepter K, Elmets CA, et al. Analysis of tumor-infiltrating lymphocytes in cutaneous squamous cell carcinoma. Arch Dermatol. 1997;133(5):585-90.

21. García-Pedrero JM, Martínez-Camblor P, Diaz-Coto S, et al. Tumor programmed cell death ligand 1 expression correlates with nodal metastasis in patients with cutaneous squamous cell carcinoma of the head and neck. J Am Acad Dermatol. 2017;77(3):527-33.

22. Chang AL, Kim J, Luciano R, et al. A case report of unresectable cutaneous squamous cell carcinoma responsive to Pembrolizumab, a programmed cell death protein 1 inhibitor. JAMA Dermatol. 2016;152(1):106-8.

23. Borradori L, Sutton B, Shayesteh P, et al. Rescue therapy with anti-programmed cell death protein 1 inhibitors of advanced cutaneous squamous cell carcinoma and basosquamous carcinoma: preliminary experience in five cases. BrJDermatol. 2016;175(6):1382-6.

24. Markham A, Duggan S. Cemiplimab: first global approval. Drugs. 2018;78(17):1841-6.

25. Migden MR, Rischin D, Schmults CD, et al. PD-1 blockade with cemiplimab in advanced cutaneous squamous-cell carcinoma. NEnglJ Med. 2018;379(4):341-51.

26. Maubec E, Boubane M, Petrow P, et al. Pembrolizumab as first line therapy in patients with unresectable squamous cell carcinoma of the skin: interim results of the phase 2 CARSKIN trial. JClin Oncol. 2018;36(15_suppl):9534.

27. https://clinicaltrials.gov, accessed 30th September, 2019

28. Herz S, Höfer T, Papapanagiotou M, et al. Checkpoint inhibitors in chronic kidney failure and an organ transplant recipient. Eur J Cancer. 2016;67:66-72.

29. Lipson EJ, Bodell MA, Kraus ES, et al. Successful administration of ipilimumab to two kidney transplantation patients with metastatic melanoma. J Clin Oncol. 2014;32(19):e69-e71.

30. Fisher J, Zeitouni N, Fan W, et al. Immune checkpoint inhibitor therapy in solid organ transplant recipients: a patient-centered systematic review. J Am Acad Dermatol. 2019; https://doi.org/10.1016/j.jaad.2019.07.005.

31. Abdel-Wahab N, Safa H, Abudayyeh A, et al. Checkpoint inhibitor therapy for cancer in solid organ transplantation recipients: an institutional experience and a systematic review of the literature. J Immunother Cancer. 2019;7(1):106-16.

Publisher's Note Springer Nature remains neutral with regard to jurisdictional claims in published maps and institutional affiliations.

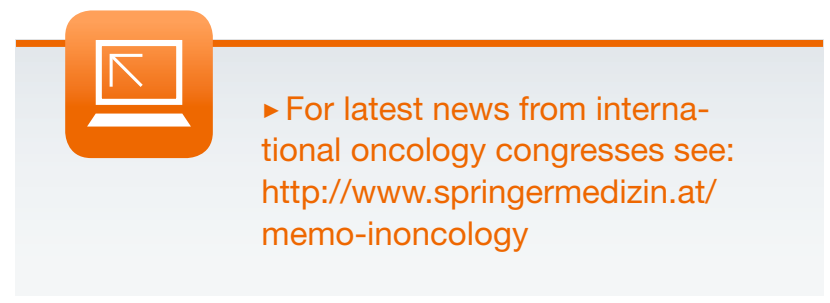

